\title{
Gift-Giving and Hospitality in Eritrean Tigrinya Society
}

\author{
Sába Tesfay \\ Eötvös Loránd University, Faculty of Social Sciences, Budapest
}

\begin{abstract}
In the present study, with the help of Eritrean examples, the author discusses how objects and visits become a means of expression for relationships and social connections. In Tigrinya society, kinship and friendly relationships have great significance, their preservation is secured by frequent visits, meetings and phone calls. They are completed by gifts, the sharing of food, contributions and loans, which move between the individuals within society, in the form of objects and money. Every transaction and exchange signifies the quality of a relationship and an event.

Starting with a summary of theories that has influenced her ideas of gift-giving, the author continues with a discussion of the types of gifts she has seen in her Eritrean field, and presents the argument that the movement of objects in society signifies the intensity and quality of social bonds and the relationship between the specific individuals involved. She also attempts to map patterns of commonality. This is followed by a discussion, in which - through interpreting objects, individuals, and occasions as signifiers -, she endeavours to outline some general characteristics of Tigrinya society.
\end{abstract}

Keywords: Eritrea, Tigrinya, gift-giving, hospitality, economic anthropology, migration

In this paper, I show through Eritrean examples how objects and visiting become markers expressing social conditions and relations. Circulating gift items and visitations make interpersonal relations closer, that is, they integrate society while also demarcating boundaries - admitting some, excluding others - so their function is "to create order in an otherwise chaotic social world". ${ }^{1}$

I find that in Eritrea ${ }^{2}$ as well as among Eritrean expatriates, the concepts of kinship and friendship are non-contractual principles which set out the obligations of individuals. The terms of kinship and friendship require that in times of need, financial or other

${ }^{1}$ ERIKSEN 2001:118 makes this apt conclusion about kinship.

${ }^{2}$ I have been conducting research in the Eritrean highlands since 2004, having spent a total of one and a half years in the field. 
assistance should be provided. In these relationships, such a code is ensured by keeping in contact, which also foreshadows that telephone conversations and in-person visits with Eritreans living abroad and with relatives living in cities are accorded just as great a significance as gifts.

In the first part of the paper, after a brief presentation of the theoretical background, I present the characteristic types of gifting I experienced in my fieldwork, and argue that the movement of objects in society indicates the intensity and quality of social relations as well as the relationship between the people involved. I seek to find out what characterizes these types of gifting. In the second part of the paper, I attempt to provide the general characteristics of Tigrinya society by interpreting objects, people and occasions as indicators.

\section{THEORETICAL BACKGROUND}

Below, I summarize the ideas about gifting in anthropological literature that have had an impact on my interpretation of the field data collected. The main points of the theoretical background are the following: a.) the concept of inalienability; b.) a demonstration of status differences; c.) the gift as a "marking service"(Douglas ISHERWOOD 1996:50-52).

During the processing of the data, I examined the relationship between goods and persons as defined by society by building on the foundations laid by Mauss (MAUss 1997:20-33). Mauss' analysis posits that gifting is an integrating force in society. The triad of giving, accepting and reciprocating is mandatory between linked individuals and groups, therefore these acts are culturally defined and regulated by moral codes. To Mauss, the gift is at once the antithesis of war: "To refuse to give, to fail to invite, just as to refuse to accept, is tantamount to declaring war" (MAUss 1997:13).

Godelier then eventually significantly diverges from them and augments his analysis when he addresses the issue of inalienable property based on his own research among the Baruya (GoDELIER 1999) embraces and further considers Mauss' findings. Following Weiner, Godelier believes that there is no society in which everything can be the object of exchange, and without the presence of sacred objects, the preservation of society would not be possible either.

So, on the one hand, objects are capable of contributing to the reproduction of society through these exchanges, a feature emphasized by Lévi-Strauss (LÉVI-STRAUSS, 1969:52-68). On the other hand, they also play a role in the preservation of identity, which in turn was underscored by Weiner (WEINER 1992:6-11). The reality of socialized objects expresses this duality. One can choose who to give to or who not to give to, but if one wants to maintain relations, i.e., to remain a social actor in society, it cannot cease to give and receive (GODELIER 1999:67). Godelier shows that valuable items "are given while being kept" (GoDELIER 1999:100), thus inalienability contains the potential joint legitimacy of these two aspects.

In my analysis, I used Weiner's and Godelier's concept of inalienability, applicable in the Eritrean examples to collective ownership, the object of which is land.

In Godelier's analysis, inalienability is inseparable from power as the inalienable objects define the political relations of the groups due to the fact that their value is not in 
the everyday practice of social existence, but rather stem from the imaginary sphere. This is just as valid among the Baruya as in Western societies (GODELIER 1999:171-200). ${ }^{3}$

The object or gift can be a means of demonstrating, marking, recording, and even altering power relations. The fact that status differences must be considered when analyzing gifting was made clear by Mauss' concept of "total services of an agonistic type" (MAuss 1997:7), an issue to which Godelier devotes considerable space, and he stresses the dual nature of the act, since solidarity is associated with superiority (GODELIER 1999:12).

Firth also addresses the gifting obligations stemming from the status differences between researcher and researched community, and declares that the a priori status differences between the anthropologist and the members of the community are determinant (FIRTH 1967:11-13).

These writings determined how I would analyze the requirements for gifting between Eritreans living abroad and those at home. Through these types of exchanges, the expectations of those back home towards the emigrants are formulated, and so is their own national identity in light of the information obtained about other countries through acquaintances and relatives. The exchanges are non-verbal expressions of the relationship between the homeland and the diaspora.

I also rely heavily on the concepts of "marking service" and "consumption ritual" by Douglas and Isherwood (DougLas - Isherwood 1996:xxii), which I find pertinent because they provide a single theory that can describe the movement of gifts and objects, as well as visits and courtesy formulas. The authors demonstrate how goods form an information system, how their use and ownership supplies information about social groups, their relationships, their members and their affiliations (Douglas IsHERWOOD 1996:xxii). How people and objects are used as markers, and thus ensure the interpretation of social processes.

A brief description of the theoretical background has served to show which factors were taken into account in my analysis of the Eritrean data. Now I will turn to the processing and interpretation of the experiences I gained in the field.

While describing the data, I try to show that in cases where the donor is an individual, the object is typically intertwined with the original owner and can replace him. The idea that an object is able to replace a person arises in Mauss' and Godelier's work. On the other hand, in my interpretation of community ownership, I found that Weiner's approach proved to be more apt, which is that land, along with other non-material values, is able to mark the continuity of the kinship group.

\section{WEDDING GIFTS}

My eldest paternal aunt, Ilen, got married in a village. Her future husband's father was no longer alive, so her future mother-in-law asked her late husband's brother to inquire after a marriageable girl at his friend's house. Ilen's father first rejected the request, arguing that even his eldest daughter was only seven years old. She [the mother of the

${ }^{3}$ Since it diverges from the subject of this study, I will not address Godelier's concept of the twin foundations of society. 
prospective husband] did not leave it at that, and insisted that some kind of an agreement be reached between the two families. To seal this agreement, the prospective motherin-law placed a necklace around Ilen's neck. For three years they remained on good terms, and the girl was ten years old when she got engaged. The boy brought a gift to the engagement party: a gold cross, clothes, and shoes. They agreed that the wedding would take place in a year and a half.

When the prospective mother-in-law placed the necklace around Ilen's neck, this indicated to everyone that the girl had been betrothed. The gift imposed an obligation upon the family and ensured that the promise was not broken. Following Mauss' train of thought, the girl's family became indebted to the boy's family (Mauss 1997:39-43). The debt started a series of exchanges, at the end of which the girl moved in with the boy's family. The gifts exchanged at the engagement party, and later during the wedding, far exceeded the value of the first necklace, hence the commitment of the two parties increased significantly. According to Sahlins, gifting following weddings is not seen as perfectly balanced among well-balanced reciprocities, because the gifts are not fully equivalent. In his opinion, if it were otherwise, any party could easily cancel the agreement, making their relationship fragile (SAHLINs 2004:223). We cannot speak of perfect symmetry in Tigrinya society even despite the fact that they continuously strive for an immediate requiting of gifts received. Frequent gift exchanges, due to the movement of objects, entails sharing of material goods, which is a basic characteristic of the family. As the transactions exceed the limits of the family, so the intimate medium becomes more extensive.

The girl puts on the clothes and jewelry received as engagement gifts with the help of her prospective mother-in-law, and sports them at the event. This is part of the gesture of accepting. The gifts are usually immediately requited by the girl's family. The countergift is known as "menlesi igre" (to be able to go home), and while in the past, or in villages even today, it consisted mainly of cattle, in cities it is now paid in cash. The girl's family always tries to reciprocate the gift received with something equal in value to the value it represents. The purpose of the counter-gift, therefore, is not to make the boy's family indebted, or to lay down a hierarchy between them, but to express the girl's family's consent and dedication to the wedding, while at the same time committing the boy's family to continuing their proposal. And the exchanges are designed to ensure each other of their generosity, which is the basis of kinship relationships.

The most precious gifts are usually exchanged by the parties on their wedding day. This is when the boy presents the gold and silver jewelry intended for the girl, the approximate value of which will be reimbursed by the girl's family. Elsewhere I presented that the amount paid, or the value of the gifts given to the bride, has increased so much that today marriage is a serious burden on both families (TESFAY 2013:14-16).

For the purpose of this paper, however, it is more interesting to examine how the gifts before and after marriage illustrate changes in relationships. Through the engagement and the wedding, an indirect acquaintance or even friendship becomes affinal kinship. This qualitative shift, by which we mean the shift from balanced reciprocity to generalized reciprocity (SAHLINS 2004:185-277), is followed by frequent gift exchanges and visits. These acts are given particular emphasis in the period when the girl and the boy are merely betrothed to each other, i.e., during the most transitional period. This is when the two families are generous with each other within their capabilities, and mutually invite each other to every family event. These include baptisms, family memorials, and 
the ngdet (feast of the church's patron saint, when every household in the area expects friends and relatives to visit).

I pointed out above that for Mauss the gift is the antithesis to war. Financial transactions before and after the wedding combine the economic interests of the two groups of concerned relatives, since with the expansion of relationships comes, to some extent, the assumption of common financial responsibility. The intertwining of interests also means that conflicts between the two families shall be prevented. This is also important because feuds between cognates are common, whereas relationships with affines are lighter, less conflict-laden - perhaps due to the fact that they do not usually come into contact on a daily basis. In Sárkány's comparative work on the exchange circumstances of four societies, the more a need-based exchange characterizes the relationship between the groups involved in marriage, the more significance is assigned to the economic aspects of marriage (SÁRKÁNY 1998:36,48,83). My understanding is that in marriage exchanges in Tigrinya society, the primary focus is on goodwill and reciprocity, as is the case among the Lovedu people that Sárkány studied (SÁRKÁNY 1998:83).

The case of my grandmother, which indicates considerable movement of goods, also illustrates the social merger of the two families through economic involvement:

When she gave birth to her seventh child, her second eldest daughter was already engaged. Upon the birth of the baby, her daughter's future father-in-law slaughtered a sheep, and brought its meat, along with sweet leavened bread, clothes, and gold, to her as gifts. In return, my grandparents gave him a big bowl of grain and a donkey. In my father's recollections, from that moment on he was free to go in and out of the future father-in-law's house. The economic side is thus inseparable from the social side, the two serving to explain each other.

The gifts are remembered clearly even after decades, and are often recounted. The gifts and their corresponding names are a basic "marking service". Marriage agreements are highly valued "low frequency" events (DOUGLAS - ISHERWOOD 1996:82-84) during which gifts are exchanged in the presence of all those gathered. The number of gathered guests, as well as the value of the gift items, indicates the prestige of the event. Items handed over in the presence of witnesses become a representation of the joining of the young couple and their families, thus becoming inalienable from their original owners. Even decades later, the act of the gift transfer ultimately recalls the giver's identity, thereby authenticating the marriage, legitimizing the present.

The financial implications of marriage agreements, on the one hand, make the relationship between the two families tighter, while, on the other hand, they create communities on both sides. ${ }^{4}$ The symbolic expression of this is seen in the temporary wedding tent, when the bride's and groom's relatives are seated facing each other and negotiate who should bring what into the new household. The event may often seem like haggling, even though today the final outcome is agreed upon in advance.

Pre-wedding gift exchanges strengthen the solidarity of both kinship groups: At my grandmother's wedding, at the bride's family alone a quintal of suwa (home-made

${ }^{4}$ The exchange of highly valuable items is significant not only for strengthening solidarity within and between the groups but also for ensuring a lasting marriage. Driberg mentions this when describing the socially disruptive impact the British colonial administration's efforts to limit the maximum value of the bride price had had (DRIBERG 1927:167-169). 
millet beer), a half quintal of gaat (polenta with spiced clarified butter), one and a half quintal of taita (bread made of teff) one and a half quintal of dagusha (a type of millet), and half a cow was consumed, the price of which, in my grandmother's determination, was a total of 500 lira. On top of this came the dowry. She claimed, furthermore, that her husband's family spent slightly more on the goods consumed at the wedding as there were more guests there. At the same time, on the revenue side for both families is the ödme, which is made up of contributions by wedding guests. On Sunday, they surveyed the gifts from the groom's family, and offered up the amount collected on Saturday. In her case, it was 1,000 liras, which was about 100 liras more than what the groom's family spent on the jewelry and clothes given to her. Back then, they could only speculate how big a gift the boy's family would bring. Everything was verified on Sunday, and if they did not come to a satisfying agreement, it could then, according to my grandmother, lead to conflicts later.

Hence, a significant part of these wedding expenses were put together by relatives and friends. Today, in the communities I have researched - in a town and in a village close to a town - a couple and their families cannot count on similar financial support; nonetheless, associations known as mahber do help their members in organizing highcost events. Mahbers can be found in urban and rural communities alike, organized partly on a religious basis and partly on a shared workplace, or a common descent, sector, or the residency of its members. Weddings and funerals are mentioned most often as events for which an individual can expect help from the mahber. In such cases, the association can lend money or tents and dishes if it has some. In the village I researched, there are several sectors which own dishes and tents; in this context, it is not insignificant, then, that these kinship units previously owned land, but now it is only the tents and dishes that are the common property of its members.

Guests contribute to the wedding of their own relatives, neighbors, and fellow villagers (ödme). These monetary or material donations occur as a function of the variables of social relations and prosperity. The mapping of the gifting, therefore, carries information related to these two variables.

Urbanization, in this regard, brought on changes that narrowed the circle of relatives who may be interested in a marriage and therefore not feel obliged to support it. Instead of donations, it is now loans that help families to marry their children. This, however, will in many cases be repaid by the young husband. So while his coming of age used to be assisted considerably by community contributions, today a young man is often connected to other members of the society through his debts. The repayment of loans is often a lengthy process and connotes a lasting bond. The movement of goods and objects - whether in the form of contributions or loans - leads to the flexibility of the social fabric: the relationships between individuals are strengthened by it. According to Sahlins, the gift creates something between the two parties: it eventuates in continuity and solidarity until it is repaid (SAHLINs 2004:208). Thus, it is obvious why socially important events involve substantial financial flows; namely, through the creation of solidary relations, the transactions ensure the reproduction of society.

According to Bourdieu, "the institutionally organised and guaranteed misrecognition,

"which is essentially the idea that both the giver and the receiver of the gift try to make the impression that they do not expect the gift to be repaid, "is the basis of gift-exchange and, 
perhaps, of all the symbolic labor intended to transmute, by the sincere fiction of a disinterested exchange, the inevitable, and inevitably interested relations imposed by kinship, neighborhood, or work, into elective relations of reciprocity: in the work of reproducing established relations through feasts, ceremonies, exchanges of gifts, visits or courtesies, and, above all, marriages."

(BOURDIEU 1995:171)

In the context of the newly formed relationships, this has particular significance. While the Nuer were capable of expressing affinal relations through the transfer of cattle (EvANS-PRITCHARD 1940:16-17), the most important source of livelihood for the Tigrinya was arable land, which, being communal property, played a role in marriage transactions only in exceptional cases. So neither communal land, nor animals played a role in the exchanges accompanying marriage. Instead of this, holidays, exchanged gifts, visits, and mutual displays of respect form the basis of reproducing already established relationships, "which is no less vital to the existence of the group than the reproduction of the economic bases of its existence" (BouRdIEU 1995:171).

\section{CHRISTMAS GIFTING AND KEEPING IN TOUCH WITH EXPATRIATES}

One Christmas, my grandmother, who lives in a village, received a plastic Christmas tree as a gift from her daughter living in Germany. Every year around December, they set up the tree and place under it the postcards and photos received from relatives in previous years.

Among the locals, gift-giving around this time is not typical; instead, they visit each other, and may bring along some pastries or coffee, which they consume together. Relatives living abroad would call their closest family members and ask about everyone back home.

The holiday thus offers them the opportunity to express their solidarity on the basis of kinship or friendship. In this case, postcards or phone calls substitute individuals. Sometimes festively wrapped boxes are also placed under the tree, but they do not contain gifts.

How can a kinship-based society deal with the continuous emigration of its members, where one's place in the village is still determined by kinship affiliation and the group is an individual's mainstay? Neighbors, friends, acquaintances often visit each other. Presence is a visible sign of fostering a relationship. Within the village, children are often sent to others with messages, and they often bring something along, as well as get a bite to eat. Sometimes they even carry the wedding contribution when the invitee is not available in person. One is thus substitutable by a postcard, a family photograph, or a child. (It is not insignificant, however, that these substitutes carry less prestige than the invitee showing up at the event.) All these carry something personal, though, and are therefore inalienable from their original owner: the child is directly linked to the parents through blood; monetary gifts are registered in the wedding tent with the donor's name; the photos show the donor and his/her family; and the postcard was sent and written personally by the donor.

When the holiday dictates that family and friends gather together, expatriate family members substitute their presence with objects (postcards, photos, phone calls). In reference to the use of mobile phones, Smith notes that in addition to the spread of mobile phones in Nigerian society as status indicators, their role in distribution and reciprocity should also be emphasized. Those who can afford to charge their phones are sometimes 
obligated, other times free to decide whether to share it with others by calling them back or contacting them. The proper use of mobile phones fits into the existing social order while complementing the established forms of social contact. The phone is often used as if to pop in on someone, ask about their well-being, and therefore its social value is high (SмITH 2007:245-248). Possession of the device not only saves time but also makes the individual available to friends and relatives. According to Douglas and Isherwood, these two factors lead to social differences (DougLAS - IsHERWOOD 1996:90-92). Everyone wants to be a mobile phone owner. Those who cannot afford one use their friends' phones to call their friends when necessary. Although there is no transfer of property, someone must assume the costs and, as Smith noted with regard to the Nigerian scenario, airtime credits are not considered to be loan debts among the Tigrinya either. Instead, the phone provides the opportunity to accumulate symbolic capital, thus giving it the ability to create social differences. "Once one realises that symbolic capital is always credit, in the widest sense of the word, i.e., the line of advance which the group alone can grant those who give it the best material and symbolic guarantees, it can be seen that the exhibition of symbolic capital (which is always very expensive in economic terms) is one of the mechanisms which (no doubt universally) make capital go to capital." (BOURDIEU 1995:181) However, the relationship between the symbolic capital and the financial capital is generally not revealed. The used credits are not reimbursed by anyone, but the owner's symbolic capital increases.

Bourdieu's thoughts help us understand how a relationship can survive even if the gift remains unrequited. The concept of symbolic capital provides an explanation for this. Mauss describes the giving, receiving and requiting of the gift as binding, and attributes the initiative to the fact that giving creates an obligation (Mauss 1997:10-14). Among competing types of total services, the lack of recompense could mean that the person failing to meet his or her obligation falls behind (CRONK 1997:157). In essence, this can happen if the parties involved are compeers and might be engaged in a status competition. At the same time, there are many different examples in anthropological literature of cultural practices that prevent the formation of status differences arising from distribution (LEE 1997:26-33). ${ }^{5}$ In the following, I address the status differences gifting creates in Tigrinya society.

\section{THE STATUS OF EXPATRIATES AND THEIR GIFTS}

Mobile phone ownership conveys a certain financial position, as does living abroad and coming home for a visit. Thus, possession of certain objects and one's residence creates status differences, often becoming expressions of unequal social relationships.

Following in Mauss' footsteps, Godelier emphasizes that during gifting a doubleedged relationship is established: on the one hand, a sign of solidarity, as one shares their possessions with the other person; on the other hand, a sign of superiority, as by their acceptance the other person acknowledges their debt and subordination (GoDELIER 1999:12). I pointed out earlier that Bourdieu resolves the same situation through the notion of symbolic capital, in which, instead of subordination, a credit redeemable for

\footnotetext{
${ }^{5}$ Richard Borshay Lee's classic case study shows which cultural practices the !Kung Bushmen employ to prevent the formation of status differences. Contrary to the author's expectations, the friends of the !Kung Bushmen did not praise but rather decried the gifts they received.
} 
material things emerges. According to Godelier, however, because of this dual role, gifting can be defined by both generosity and violence.

Considering that diaspora Eritreans come home for a visit packed with gifts for loved ones, firmly unequal relations are safe to assume. (It is typically upon departure that residents provide their emigrant relatives with domestic foods and grains, i.e., goods which could not be purchased abroad.) This is due to both financial reasons as well as a notion of the world outside of Eritrea. Gifts can only confirm this world, and the more objects indicating the presence of foreign visitors, the richer the picture of the "foreign land" that emerges among the locals. Each family strives to help one or more of its members go abroad. Taking someone home in a suitcase is the eternal object of jokes. Among locals, living abroad is the same as having the opportunity to get rich. This, too, is confirmed by the gifts that are sent home. Therefore, the superiority latent in gifting ranks the members of society, and Eritreans living abroad become the privileged group. Gifting of this nature, like donation, helps preserve influence and status hierarchy.

The Eritrean government recognized the integrative role of such transactions when it decreed that Eritreans living abroad should pay $2 \%$ of their salary to the state in order to keep their citizenship and be able to purchase realty. Otherwise they lose the benefits of citizenship. This concept, however, also entails the notion that the land, the native land is in the hands of the government empowered by the "nation", Previously, administration of the lands providing their livelihood was handled by sectors, just as land was owned by kinship groups. Individuals could receive arable land through their sectoral affiliation. The Ethiopian Dergue ${ }^{6}$ land law of 1975, and later the independent Eritrean government, identified the state as the owner of the land in 1994. At the same time, entitlement was tied to service in the interest of the nation. In this Tronvoll sees the state's efforts to fracture the corporate cohesion of close-knit rural communities and confining the individual directly to the state apparatus (TrONVOLL 1998:277).

Neither today, nor in the past was land ever the subject of bargaining and exchange - except in some special cases. Land has always been possessed by a kinship group, and it has secured the financial basis of the group; the group's reproduction depended on it, as did its ability to maintain continuity independent of individuals. Hence the unity of the land and the people living on it. Just as kinship - and its structural units, the sectors - ensures the continuity of the group and links those living now to the past and the present alike, land does the same by being community property (LÉVI-STRAuss 1969:46). ${ }^{7}$

The kinship map reflects the real geographical terrain (BoHANnAN 1963:105). ${ }^{8}$ The houses and plots of agnatic relatives are located adjacent to each other (land reform makes this impossible today, but it can still be clearly seen in village housing). Apart from Muslims, over time all settlers became members of one of the sectors, and in such a way so as not to contradict the structural principle of kinship and land. In other words, an individual's admission first happened within the family, and if they managed to get access to land (through the influence of the head of the family), their sectoral affiliation

\footnotetext{
${ }^{6}$ Derg or Dergue is the name of the military regime in Ethiopia between 1974 and 1987.

${ }^{7}$ Lévi-Strauss makes a similar observation about yam in Dobu, stressing that the production and distribution of yam ensures the continuity of groups, i.e., yam reproduces similarly to human groups.

${ }^{8}$ Paul Bohannan makes a similar observation about the Tiv in Nigeria.
} 
was then also resolved. The numerous confusing genealogies were then soon forgotten by the group (TESFAY 2014).

Kinship therefore means an inalienable status while land is an inalienable property. The intertwining and inalienability of the two made it possible for individuals to share their wealth with each other because, on the one hand, these two secured the assets that were included in the exchange, and, on the other hand, they meant financial security.

This principle was recognized by the government when it made the state the owner of lands, and by which it partly took over the role of the sectors. Since it became owner of the land, the state seized a function that previously belonged to a kinship group.

However, this also needs a cultural justification. In his conclusions, Sárkány points out that culture is the determinant of the exchanges. He calls this social background and notes that in different societies different factors may predominate (SÁRKÁNY 1998:106). In Tigrinya society, these factors are kinship, marriage relations, and their associated customs and traditions (bahli). It is no coincidence either that the events vital to the group's reproduction - births, weddings and deaths ${ }^{9}$ - are accompanied by customs during which the home and the cultural roots are given great importance. Each transition is accompanied by rituals in which we encounter the exact terminology of home and descent.

It seems as if the living were tied to their original home by an invisible thread. Heads of families living in Asmara build a house in Adi, ${ }^{10}$ while the emigrants build them in the capital. Many people retain their influence in their native village and participate in committees managing the political life of the village. Upon the initiative of men living in the capital, in 2006 a dispute between Adi and a neighboring village was resolved that reached back to the time of Italian control. The village expects help from its expatriates in exchange for influence, status and prestige. Those who donate to the local church on the occasion of religious and family celebrations are highly esteemed. They also remember if someone lends a car to carry the bier of a deceased relative or to transport a wedding party. This system is based on the structural relationship between the village and the city.

\footnotetext{
${ }^{9}$ Childbirth: Usually the young, married woman has been living in her new home with her husband, but in the weeks leading up to the birth, she goes home to her mother and stays there until the child is born. Women who marry abroad and cannot return home will summon their mother for the birth, if possible. Wedding: The home also plays an important role during the wedding: the two main venues of the two-day-long festivities are usually the tents set up at the groom' and bride's houses, each filled with relatives and friends of either party. On the second afternoon, they carry around the gifts bought for the bride, calling out loud what each receives and brings into the marriage, and then the wedding concludes at the groom's tent. By now the bride belongs to her husband's group. The biggest weddings are held by diaspora Eritreans or are financed with their help. Many of them choose an Eritrean mate in their new home, or they select a suitable partner from the wider circle of family acquaintances through the mediation of relatives back home. There are some who marry abroad but years later renew their vows in the circle of their family at home. In their case, the wedding is of particular importance. For them, this occasion is an expression of the link between the family left at home and the emigrant offspring, the validation of the marriage among those at home, the confirmation of the respect and bond among relatives, and an event in which the emigrants provide a compact display of everything that their Eritrean home, their family means to them.

Funeral: Lastly, the home plays a role even during the funeral and the vigil. Wherever a man lived, he will be buried in his native village, and his wife is going to rest in the same place. The 12-day vigil (hazen) takes place in a tent set up next to the house in which the deceased's closest relatives live, that is, at the home of the husband/wife or the eldest male descendant.

${ }^{10}$ My field is a village near a major city, which appears in the paper as Adi.
} 
We can see, therefore, that kinship, culture, the symbolic substance of home, the relationship to the land - all of it supported by religion - make an ensemble in which the individual is connected to the group through invisible fibers. These latent relationships become visible during certain occasions, events that are important to the community, such as weddings or funerals. But since they are latent, their survival must be ensured occasionally, especially if an individual is unable to attend the celebrations reinforcing these relationships. In such cases, phone calls or gifts from the expatriates may serve to reinforce the intent.

As in many other societies, rites of passage provide opportunities for gifting and significant financial transactions. In reference to Somalis, Rousseau et al. emphasize the role of gift-giving in riding out the hazardous period brought on by social and personal transitions and changes (RoussEAU et al. 1998:404). The gift links those who will be parted, and the object can be taken or sent from the known to the unknown, and "gifts fill the gaps of empty liminal spaces with additional meaning" (RousSEAU et al. 1998:404). Thus, objects and transactions are capable of holding together split families as long as both sides feel the need to do so.

Cliggett argues that Zambian migrants send home gifts of lesser value as a way to try to ensure their own future well-being in this troubled world. Although most of them have to make great sacrifices to send home even the smallest gift, yet they still do, otherwise their relatives may turn away from them in their old age, when they will need support upon their return. In lieu of something else, they may even send home their wives to assist their mother in her home (CLIGGETT 2003:543,547). In the communities Cliggett studied, it was mainly those who lived in poverty that tried to maintain contacts, as their future was not secured in the city. The situation is different among emigrant and citydwelling Eritreans. Many of those living in the diaspora plan to return home in their old age. To this end, it is necessary to create financial security. Diaspora Eritreans typically preserve their customs, try to create conditions reminiscent of their home, with special emphasis on meals. The hope of returning home, the cost of phone calls and visits home are sustained particularly by Eritreans with a strong livelihood.

The authors summarizing the results of research conducted among Somali refugees show that it is unimaginable - stemming from a basically nomadic livestock-raising past - that a man should return to his family empty-handed from a trip or overseas endeavor due to failure. Learning or financial gain is necessary to confirm the traveler's fortitude (Rousseau et al. 1998:390). The community's expectations, like those in the Somali example, can also be observed in Eritrean society.

Ultimately - as in Cliggett's Zambian example, and as a fulfillment of community expectations - migration creates unequal parties. The emigrant that expects to retain the attention of those left at home needs to invest in the relationship. While emigrant Eritreans represent the upper crust, we have seen that those at home can have command of the value constituting the group's essential property. This includes land and kinship. This is what constitutes inalienable property among the Tigrinya (WEINER 1992:150; GoDELIER 1999:111-121). Based on this, we have to agree with Godelier who, departing from Maussian tradition, ascribes inalienability mainly to social causes (GoDELIER 1999:45). 


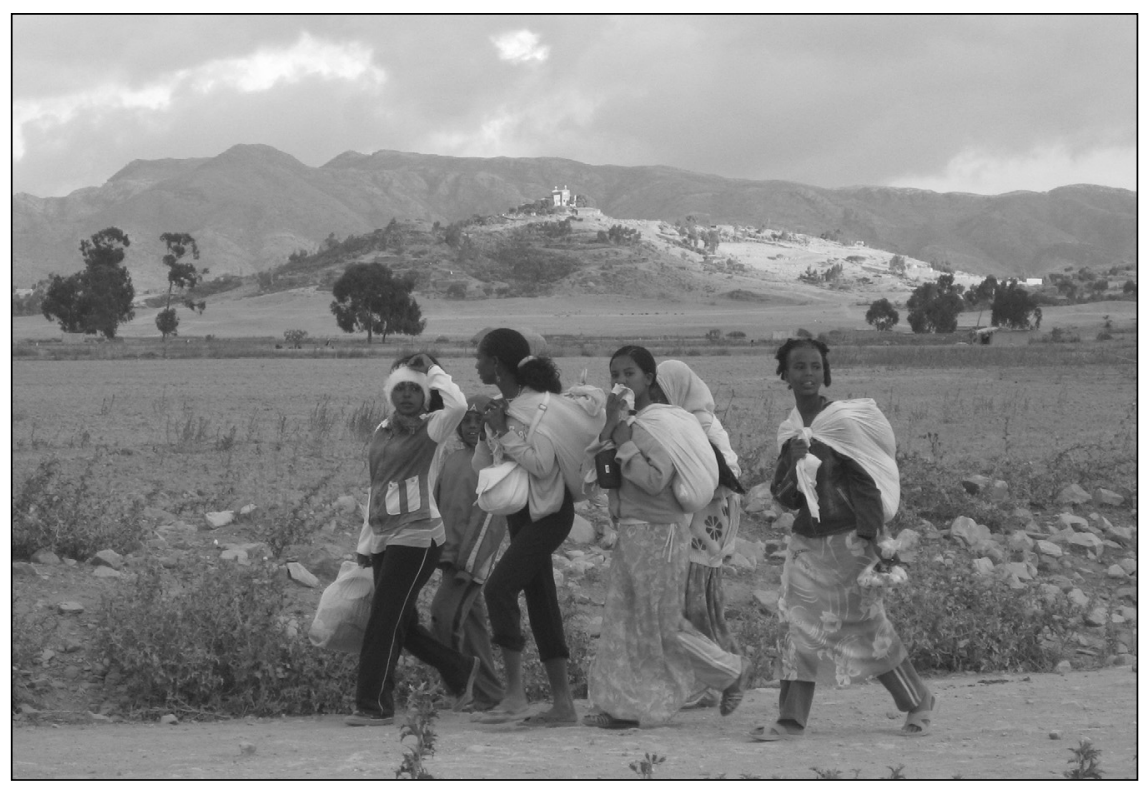

Figure 1. Young girls from the countryside often travel on foot from village to town to supplement their supplies with the products available there. Eritrea, Zoba Maekel, 2008. (Photo by Sába Tesfay)

\section{VISITATIONS AND THE SHARING OF FOOD}

It is befitting to reciprocate the visits, just the same as the gifts. Mutual visitations are actually about the distribution of food, and as such, discussing it within the context of reciprocity may be promising (LÉvi-STRAuSs 1969:55). "Primitive thought unanimously proclaims that: 'food ... is something that has to be shared"' (LÉvi-STrauss 1969:33). Sahlins believes that food represents a unique social value ("Socially they are not quite anything else"), and, stemming from this, its distribution within the community must take the form of generalized reciprocity (SAHLINS 2004:215). Sárkány does not agree; in the cases of the groups he studied, he blames the lack of food items in the exchanges on the methods of food acquisition and the low quality of preservation activities. $\mathrm{He}$ does not rule out that there may be places where social mores prohibit the sale of food, but it can by no means be generalized (SÁRKÁNY 1998:97-98). Among the rural Tigrinya I studied - who lived in the vicinity of the city - Sárkány's observation that the community was able to produce for itself pretty much the same food as what they would receive as a gift so it was unnecessary to acquire it through the exchange seems valid (SÁRKÁNY 1998:97). In the economic sense, this explains why food was not sold. However, it remains a question why the Tigrinya attach so much importance to the community feasts accompanying the holidays where one can witness large-scale food distribution. For me, the answer lies with Sahlins and Lévi-Strauss, who see the sharing of food and drink as an opportunity to establish or refuse friendly relations (LÉVI-STRAUSS 1969:58-59; SAHLINS 2004:216). 
Among the Tigrinya, catering provides the most typical form of food distribution. All prestigious events (wedding, christening, vigil, graduation, the visit of a relative who lives far away, the local church's patron saint's feast [ngdet], Christmas, Easter, etc.) are opportunities to provide abundant feasts to visitors. ${ }^{11}$ Among these, the wedding, the $n g d e t$ and the vigil deserve special attention, because these three are not strictly affairs of the immediate family but ones that mobilize the whole kinship and neighborhood. The more people attend an event and the larger the financial transactions, the more important the social role one can attribute it. That is, attendance and transactions ensure the event's prestige. However, since these two are not just for family members, one can speak of significant redistribution.

Within the family, the mother, the grown woman keeps track of and collects information about funerals, weddings, sick children, and people in need of help. One of my urban female relatives attended three weddings and two funerals within three months, regularly visited his girlfriend's baby in the hospital, and even attended four or five gatherings where someone was either sent off to or welcomed back from a long journey. In the evenings, she would watch her sister's wedding video. Women have the task of maintaining relations, and their husbands can join them. Catering is also the women's responsibility; therefore, they assume a primary role in the redistribution of food.

Upon my last visit to my rural relatives I received eggs that were addressed to my four-year-old daughter. My aunt who lives there says this means that since I came from far away, they wanted to give me a gift, and they had nothing but the eggs laid by their own hens. Notable guests may even receive a chicken, but nowadays the villagers are less able to afford that. This whole message can be found condensed in a few eggs. This gift is not only about the obligation, but about our relationship, and even my own family status. Similarly condensed information is being communicated to us through the other exchanged foods and drinks, as well as their ingredients. ${ }^{12}$

Without going into much detail, it is worth mentioning that catering requires a lot of time from the female members of the household. It necessitates the children's constant help. The more children who can participate in household chores, the more free time the lady of

${ }^{11}$ In my grandmother's example, we saw that a significant part of the wedding expenses was contributed by rural relatives and friends. The remaining amount was supplemented by the family. Today this has changed a lot. I presented above that today's youth often use loans to cover the wedding expenses, which is supplemented by the ödme. All invitees pay a cash contribution at the entrance of the tent, which is methodically recorded in a notebook by an entrusted relative. The names of donors of larger amounts (who are mostly affluent and close relatives) are then read out loud for everyone to hear. In this case, their reward is respect, prestige and honor.

Relatives and acquaintances are also hosted for several days during vigils. "Pooling" in this case happens in a way that all relatives and visitors bring pre-made foods, which are consumed together. "From an economic view point no one has gained and no one has lost" (LÉvi-STRAuss 1969:59). The prepared food cannot be used for profiteering. Rather, sharing the food is intended to express the cordial relationship. Thus, the redistribution of the food consumed on the occasion of a wedding or a vigil serves to integrate the members of the community.

${ }^{12}$ To reciprocate warm hospitality is befitting. While it used to be sugar, today a bottle of araki (anise distillate) or pastry are the most common gifts that visitors can bring. A close relative can show up without a gift. Food distribution in this case actually takes the form of generalized reciprocity. In addition to the quality of the relationship, gifts also reveal the financial background of the parties and the occasion of their meeting. 
the house has and the more guest she can accommodate. An affluent family may even hire a servant, but the help of the older children is still needed. This serves as a backdrop for family prestige. A household where three or four individuals are constantly bustling around certainly enjoys a higher social status than one where the mother does everything.

A city woman, who usually has a higher prestige than a village woman, can dedicate a significant part of her time to the preparation of meals. The higher the status of a family, including their financial status, the number of their children and their age as well, the greater the number of guests they can accommodate - as they are doing. Villagers with less income and less free time can only provide a modest replica of that. It can also be observed that the more affluent heads of families - due to owning a car and a telephone and being able to afford to regularly contribute to the events of their relatives and acquaintances - attend weddings more frequently or become hosts or guests. Their financial circumstance, their status imposes a broader social involvement upon them.

This all implies that hospitality, catering has a high social value. Persons and occasions are basic "marking services" (DougLAS - ISHERWOOD 1996:50-52). They focus on consumption. The amounts consumed and the number of attendees indicate the rank of the event and the family. Beyond the quantitative indicators, who attended the event and what they consumed also serve as indicators. In this regard, social consensus is the benchmark. This consensus is behind the reality that hospitality carries hidden information about the financial background of the households and the relationship between them. Consumption is a social act, and in Tigrinya society, its examination is only possible within the system of its kinship, friendship and economic aspects. This system allows the ranking of the constituent units of society, attributing high status to the largest households, hence able to host the most costly events. Because of this, weddings, $n g d e t s$, and even church donations have indicator value in this area.

\section{MONEY VERSUS GIFT}

In my grandmother's time, the man gave money to his new wife on their wedding night. They pressed bills to the dancers' foreheads and clothes when they wanted to express approval. Urban relatives visiting their rural kin may also give money, including to children. Wedding guests contribute to the event with money. Money is morally neutral, and as such, it seemingly contradicts the view that Western money is liable for the collapse of the moral economy (BLOCH 1996:166; BoHANNAN 1959). Like the gifts, it strengthens the existing kinship ties.

"It comes hard, goes easy," said one elderly villager. Money is liquid (DougLas 1967:139). For this reason, there is a need for tools that can compensate for this property. The above-mentioned mahber associations fulfill this task because members support those in need with an amount stipulated at the monthly or annual meetings. In this regard, then, money does not hinder intimate relationships and friendships; on the contrary, loans, contributions and membership fees take on the function of integrating the social fabric. 


\section{CONCLUSIONS}

In Tigrinya society, kinship and friendly relations are given great importance, and their maintenance is ensured by frequent visits, meetings and telephone conversations. These are complemented by the gifts, the sharing of food, contributions and loans, which move in the form of objects and money among the individuals that make up society. All transactions and exchanges indicate the quality of the relationship and the prestige of the event. This system is imposed upon the members by the culture, a tradition that gets transmitted within the family and the immediate environment. This is the root of the significance of keeping track of mate choice and descent. In America, Eritrean men marry girls from Asmara that were selected for them by their close - predominantly female relatives. On the one hand, culture requires these young girls to lead a modest and chaste life in their pre-wedding years, befitting the social norms, because only their and their family's reputation can bring them the long-awaited "prince" (OTNES - PLEC 2003:12). At the same time, this also explains why diaspora Eritreans form such an integral part of the home communities. In this way, because of the exchange of women, words and objects, the cultural reproduction continues abroad (LÉVI-STRAuss 1969). All of this seems to support the following statement by Lévi-Strauss: "There is no need to call upon the matrimonial vocabulary of Great Russia (...) for the likening of women to commodities, not only scarce but essential to the life of the group, to be acknowledged" (LÉVI-STRAUSS 1969:33). That is, the Eritreanness of foreigners feeds on the home medium.

Things are given their meaning through human transactions (APPADURAI 2008:63). Similarly to the Tigrinya, these meanings are unequivocal in all densely woven social environments. Specific occasions call for the movement of specific goods.

To live as a member of society means that the individual is involved in community transactions. Among the Tigrinya, the community becomes a visible group on the occasion of major events - not just to the outside observer, but also to the participants. They represent the community whose members are linked by long-term obligations.

\section{REFERENCES CITED}

APPADURAI, Arjun

1988 Introduction. Commodities and the Value of Politics. In APPADURAI, Arjun (ed) The Social Life of Things. The Commodities in Cultural Perspectives, 3-63. Cambridge: Cambridge University Press.

BLOCH, Maurice

1996 The Symbolism of Money in Imerina. In PARRY, Jonathan - BLOCH, Maurice (ed) Money and the Morality of Exchange, 165-190. Cambridge: Cambridge University Press.

Bohannan, Paul

1959 The Impact of Money on an African Subsistence Economy. The Journal of Economic History 19(4):491-503.

1963 'Land', 'Tenure' and Land-Tenure. In BIEBUYCK, Daniel (ed): African Agrarian Systems, 101-115. London: Oxford University Press. 


\section{BOURDIEU, Pierre}

1995 Symbolic Capital. In Bourdieu, Pierre (ed) Outline of a Theory of Practice, 171-183. Cambridge: Cambridge University Press

Cliggett, Lisa

2003 Gift Remitting and Alliance Building in Zambian Modernity. Old Answers to Modern Problems. American Anhtropologist 105(3):543-552.

Cronk, Lee

1997 Reciprocity and the Power of Giving. In Spradley, Barbara A. - McCurdy, David W. (eds) Conformity and Conflict. Readings in Cultural Anthropology. $9^{\text {th }}$ edition, 157-163. New York: Longman.

Douglas, Mary

1967 Primitive Rationing. A Controlled Study in Exchange. In FiRTH, Raymond (ed) Themes in Economic Anthropology, 119-148. London: Tavistock.

Douglas, Mary - BARON Isherwood

1996 The World of Goods. New York: Routledge.

DRIBERG, J. H.

1927 Anthropology Colonial Administration. Economica XX:155-171.

ERIKSEN, Thomas Hylland

2001 Small Places - Large Issues. London: Pluto Press.

EvANS-PRITCHARD, Edward

1940 The Nuer. A Description of the Modes of Livelihood and Political Institutions of a Nilotic People. Oxford: Clarendon Press.

FIRTH, Raymond

1967 Themes in Economic Anthropology. In FIRTH, Raymond (ed) Themes in Economic Anthropology, 1-28. London: Tavistock Publications.

GoDELIER, Maurice

1999 The Enigma of the Gift. Cambridge: Polity Press.

LEE, Richard Borshay

1997 Eating Christmas in the Kalahari. In Spradley, Barbara A. - McCurdy. David W. (ed) Conformity and Conflict. Readings in Cultural Anthropology. $9^{\text {th }}$ edition, 26-33. New York: Longman.

LÉvi-STrauss, Claude

1969 The Elementary Structures of Kinship. Boston: Beacon Press.

Mauss, Marcel

1997 The Gift. The Form and Reason for Exchanges in Archaic Societies. London: Routledge.

Otnes, Cele C. - Pleck, Elizabeth H.

2003 Cinderella Dreams. Berkeley and Los Angeles: University of California Press.

Rousseau, C. - TM. Said - MJ. Gagne - G. Bibeau

1998 Between Myth and Madness. The Premigration Dream of Leaving Among Young Somali Refugees. Culture, Medicine and Psychiatry 22:385-411.

SAHLINS, Marshall

2004 Stone Age Economics. London: Routledge.

SÁRKÁNY, Mihály

1989 Exchanges between Communities. Budapest: Ethnographic Research Institute. 
SMITH, Daniel Jordan

2007 Cell Phones, Sharing, and Social Status in an African Society. In PoDolefsKy, Aaron - Brown, Peter (ed) Applying Cultural Anthropology. An Introductory Reader. $7^{\text {th }}$ edition, J. 242-248. New York: Mc Graw Hill.

TESFAY, Sába

2013 Costly Revelry - Growing wedding expenses among the Tigrinya of Eritrea. Afrika Tanulmányok (Africa Studies) 7(4):5-18.

2014 Secret Genealogies in an Eritrean village. In SchILlER, Katalin - TóTHKIRzSA, Fruzsina (eds) Mwomboko. A Festschrift for Mihály Sárkány's 70 ${ }^{\text {th }}$ birthday, 42-57. Budapest: MAKAT-ELTE BTK Ethnographic Institute.

TronVOLL, Kjetil

1998 Mai Weini. Asmara: The Red Sea Press.

WeINER, Annette B.

1992 Inalienable Possessions. The Paradox of Keeping-While-Giving. Berkeley: University of California Press.

Sába Tesfay teaches cultural and social anthropology as an assistant lecturer at the Eötvös Loránd University, Faculty of Social Sciences, Budapest. She has spent 18 months in Eritrea doing research for her MA and later PhD thesis. Her major fields of interest are African studies, migration, land tenure systems and kinship relations. Email-address: tesfayss@ yahoo.com 